
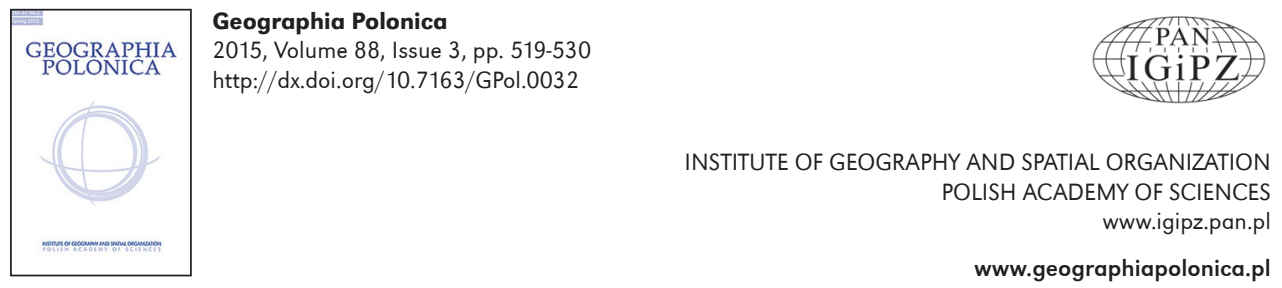

\title{
SPATIALLY EXPLICIT CHANGES IN LAND OWNERSHIP THROUGH 3 SOCIO-POLITICAL SYSTEMS: A CASE STUDY FROM SOUTHEAST POLAND
}

\author{
Andrzej Affek \\ Institute of Geography and Spatial Organization \\ Polish Academy of Sciences \\ Twarda 51/55, 00-818 Warsaw: Poland \\ e-mail: a.affek@twarda.pan.pl
}

\begin{abstract}
Spatially explicit analysis of land ownership changes can provide a unique opportunity to trace land ownership and determine spatial patterns of inheritance. In this paper, the structure of land ownership in the age of feudalism (1852), communism (1965) and capitalism (2008) was reconstructed for a landscape-scale study area - the Upper Wiar River Basin in the Polish Eastern Carpathians. Austrian cadastre and post-war land registers were used as source data. Trajectories of land ownership changes were mapped and discussed. The similarity of landowner types was determined by means of correspondence analysis. The results generally showed how highly unstable land ownership is when socio-political systems are in flux.
\end{abstract}

\section{Key words}

Austrian cadastre $\cdot$ land register $\bullet$ trajectories of landowners $\bullet$ feudalism $\bullet$ communism - capitalism • Upper Wiar River Basin

\section{Introduction}

Long-term studies of land ownership transformations are very rarely spatially explicit. This is because obtaining and processing detailed archival cartographic data is complicated and time consuming. This applies in particular to landscape-scale studies, where the amount of data is often overwhelming. However, this is the only way to reveal trajectories of ownership changes over centuries for a certain piece of land. The analysis of aggregated census data, which is fast and quite common, provides only knowledge of net percentage 
changes without taking into account gross changes and spatial distribution.

The aim of this paper is to present spatially explicit structure of land ownership in 3 sociopolitical systems (feudalism, communism, capitalism) and characterize the 'paths of inheritance' in the Upper Wiar River Basin (Polish Eastern Carpathians), which is a particularly highly dynamic area for any spatial structures (natural or human) within the time horizon of the research.

\section{Study area}

The study area of $233 \mathrm{~km}^{2}$ roughly coincides with the Upper Wiar River Basin, located in Poland on the northern fringe of the Carpathian Mountains, close to the contemporary Polish-Ukrainian border and the cities of Dobromil and Przemyśl. For practical reasons, the boundaries of the study area were adjusted to match the village boundaries of the mid-19th century. In 1368, the Upper Wiar River Basin as a whole was given to one owner - Stefan Węgrzyn, ancestor of the Rybotycki family (Wolski 1956), for the purposes of colonization. This is why even major administrative boundaries up to World War II were highly consistent with the watershed line. Only the appearance of the state border near the study area after World War II, and the resulting division of the Dobromil District (Dobromil was left on the Soviet side), resulted in a shift of the centuries-old administrative boundaries.

Until the mid-1940s it was a highly-populated, hilly rural area, considered an ethnic borderland inhabited by both Poles and Ukrainians. There were 24 villages and one town - Rybotycze. After the war, the Ukrainians were forcibly displaced following political decisions by Poland's communist government. The population density decreased from 80 people $/ \mathrm{km}^{2}$ in 1939 to less than 10 peo$\mathrm{ple} / \mathrm{km}^{2}$ in 1950 (Affek 2015). Demographic changes were accompanied by agrarian reforms involving expropriation and nationalization of land. From 1970 to 1990 in the central, desolate part of the study area, there also functioned a hunting resort 'Arłamów', for the Council of Ministers Office.

Standing in the reality of a free market economy after the political transformations of 1989, these hilly, peripheral lands suffered from agricultural marginalization. But most of the basin has now been covered by some form of nature conservation, and it is the recreational values of the region that are gradually becoming more important.

\section{Source materials}

The only complete, spatially explicit dataset presenting the state of pre-war feudal land ownership in the study area is the one resulting from the Austrian Stable Cadastral Survey conducted in 1852 (Tab. 1). The Stable Cadastre (Stabiler Kataster) consists of cartographic and descriptive parts elaborated separately for each cadastral community (town or major village) (for details see Surowiec 1982; Wolski 2000). The basic cartographic material was a full colour cadastral map at a scale of 1:2,880, showing land parcels, buildings and some additional topographic features (e.g. land cover, watercourses, roads, toponyms).

In the mid-19th century, beside the foundation of a constantly updated cadastre, lithographic copies of cadastral maps were made, as well as copies of landowners' records, and these are currently stored in the state archives. These copies are free of any updates, so there is no difficulty determining the initial ownership structure from them. The original Austrian cadastral maps and their lithographic copies of the Upper Wiar River Basin were found in several places: the State Archives of Rzeszów, Przemyśl and Ustrzyki Dolne; in the Central State Historical Archives of Ukraine in Lviv; in the District Offices of Przemyśl and Ustrzyki Dolne, and in the Municipal Office of Fredropol. Thanks to a large-scale enquiry, cadastral maps for 1852 for the entire study area (a total of 25 cadastral communities) were found and collected together in digitized form (Fig. 1). 


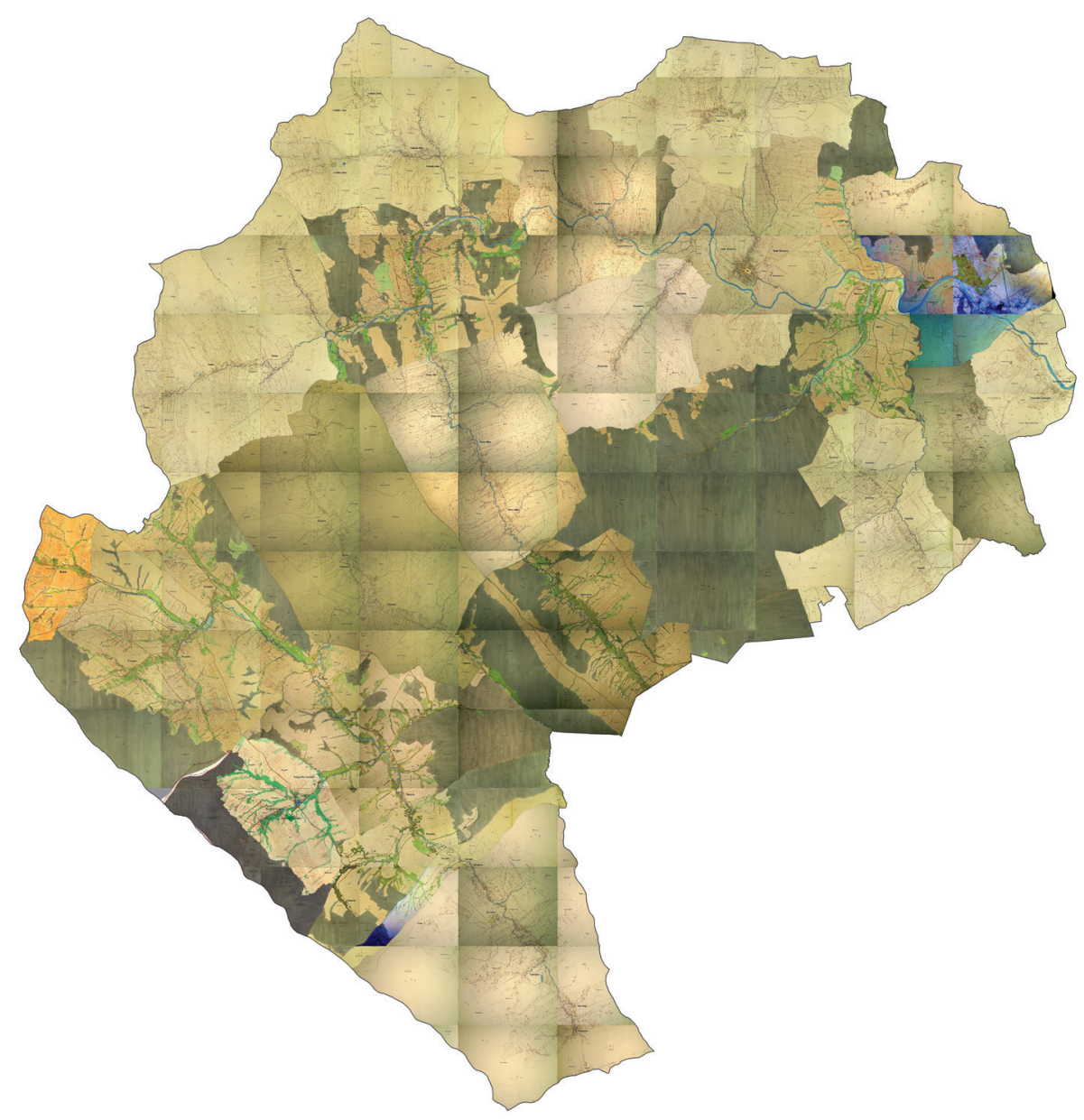

Figure 1. Mosaic of scanned sheets of the Austrian cadastral maps depicting the whole Upper Wiar River Basin ( 25 cadastral communities) in 1852

Source: own elaboration based on source materials in a 1:2,880 scale, from the State Archives in Rzeszów and Przemyśl and the District Office in Przemyśl

All materials collected from the descriptive part of the Austrian cadastre come from the Fonds 126 'Geodetic Archive' of the State Archive in Przemyśl. The Alphabetical lists of landholders (Alphabetisches Verzeichniss) were considered to be the best descriptive source materials for reconstructing links between owners and land parcels. These lists, found for 18 out of 25 cadastral communities, explicitly record the assignment of parcels to their owners. Most of the missing data were taken from notes plotted on field sketches.

After the turbulence of the 1940s, the district land registry was hardly functional. No data were found from the first post-war nationwide land registration, based on surveys, which anyway were probably not even carried out in the study area. In all matters related to spatial planning the outdated Austrian cadastral maps continued to be used. In the 1950s the initiative was taken by the 
Table 1. Source materials for the reconstruction of land ownership in 3 socio-political systems

\begin{tabular}{|c|l|c|l|c|}
\hline $\begin{array}{c}\text { Socio- } \\
\text { political } \\
\text { system }\end{array}$ & \multicolumn{1}{|c|}{ Material } & Date & \multicolumn{1}{c|}{$\begin{array}{c}\text { Source } \\
\text { of parcels }\end{array}$} \\
\hline Feudalism & Austrian Stable Cadastre & 1852 & $\begin{array}{l}\text { State Archives of Rzeszów } \\
\text { and Przemyśl, District Offices } \\
\text { of Przemyśl and Ustrzyki Dolne, } \\
\text { the Municipal Office of Fredropol } \\
\text { Communism }\end{array}$ & Second stage of land registration \\
Capitalism & $\begin{array}{l}\text { Land-parcel identification system } \\
\text { Register of land and buildings }\end{array}$ & 2008 & $\begin{array}{l}\text { Ustrzyki Dolne of Przemyśl and } \\
\text { Head Office of Geodesy and } \\
\text { Cartography, District Office } \\
\text { of Przemyśl and Ustrzyki Dolne }\end{array}$ & 9,031 \\
\hline
\end{tabular}

'State Forests' National Forest Holding, and the 'State Farms' National Agricultural Holding, which mapped the temporary boundaries of their properties. It was only in the mid-1960s that the so-called Second stage of land registration was conducted, which laid the foundations for the first full post-war land registry.

Documents from the Second stage of land registration developed for the study area in the years 1964-1967 were used as source materials for the reconstruction of land ownership structure under communism rule (Tab. 1). These materials were obtained from the archives of the District Offices in Przemyśl and Ustrzyki Dolne.

The land registers, drawn up separately for each geodesic precinct (obręb), consisted of two parts: cartographic and descriptive. Cadastral maps were of scales 1:2,000, $1: 5,000$ and even still 1:2,880. A maximum acceptable mean error of $20 \mathrm{~cm}$ was adopted for determination of parcel boundaries (Surowiec 1982). The key documents constituting the descriptive part of the land registry were a detailed land registry book, parcel index, and an alphabetical list of landowners and landholders. The land registry book contained a list of register units arranged by register groups ${ }^{2}$, along with the land

\footnotetext{
1 Register units (name of owner and unique number) are formed by land parcels located within the area of a particular geodesic precinct, and that are owned/ held by one natural or legal person.

${ }^{2}$ Land properties of similar management practices
}

parcels assigned to them, and a description (size, type of use). The parcel index consists of a list of parcels, in ascending order, along with the numbers of the register units assigned to them. The list of landowners is an alphabetical list of register units. For the purposes of this work, the author primarily made use of the parcel indexes and alphabetical lists of landowners and landholders. The detailed land registry book was then only used when one of these documents was not available.

In the study area, a paper-based land registry was maintained until the end of 1998. As of 1 January 1999, the descriptive part was replaced with a computer database - the EGiB-III (Register of Land and Buildings, Ewidencja Gruntów i Budynków). This database, current as of 2010, together with the land parcel vector layer from LPIS (Land-parcel identification system) was the source material for the reconstruction of modern land ownership structure of the capitalism era (Tab. 1). The vector layer was acquired from www.geoportal.gov.pl using their WFS (Web Feature Service) download service. According to the metadata for this resource, the layer contained data current as at 1 November 2008, generalized to $1 \mathrm{~m}$.

or land use form register groups used for statistical and analytical purposes. 


\section{Methods}

\section{Georeferencing}

Raster images of the Austrian cadastral maps were distorted by paper shrinkage and imperfections in the scanning process, but the originals, at the time of development (based on triangulation measurements), met cartometric requirements. Therefore, georeferencing was performed with the original reference system (Vienna Datum, point of origin at St. Stephan's Tower), and projection (simplified Cassini-Soldner, with the High Castle in Lviv as the prime meridian) in accordance with the procedure for maps based on geodetic networks (see Affek 2013). Affine transformation was used by default. For the more distorted sheets, a rubbersheeting spline transformation was applied. An average RMS error of $0.28 \mathrm{~mm}$ was achieved, which corresponds to $0.8 \mathrm{~m}$ in the field (affine transformation, approx. 30 points per sheet). In the next step, the sheets were mosaicked together to facilitate further map vectorization and creation of a single vector layer. As a result, a raster mosaic was created consisting of over 210 map sheets assigned to 25 cadastral communities (Fig. 1), the uncompressed file size of which exceeded 414 GB. A 3D datum transformation from Vienna local datum to the contemporary WGS_1984 global reference system was then conducted in accordance with the procedure described in detail in the article by Affek (2013).

Another issue was georeferencing cartographic materials of the 1960s from the Second stage of land registration. The only reasonable way to digitize such a large number (over 200 sheets) of the cadastral maps archived at the District Offices was to photograph them with a camera, as there were no possibilities for scanning them (some were on hard sleepers) by employees of the District Office (labour shortage, other statutory purposes). Map content distortion from simple photos is of course incomparably higher than from proper scans. However, being aware of the limitations of the process, georeferencing of the photographs was based on reference layers, using a workflow designed for maps not based on geodetic networks (see Affek 2013). Contemporary cadastral vector layer and georeferenced Austrian cadastral maps were used as reference layers. A large part of the post-war cadastral maps was a simple update of the 19th-century maps, preserving the same sheet cut and scale of 1:2,880. Distortion analysis showed that, with a sufficient number of control points on the sheet frame (4 corner points + approx. 12 at the edges), as well as a few further points within the sheet, a spline rubbersheeting-type transformation algorithm implemented to ArcGIS corrected the regular, concentric distortions caused by the lens of the camera very well. However, for this type of transformation the actual match error cannot be calculated (RMS error based on control points is 0). Undoubtedly, the mean error of object location after spline transformation was lower than after simple polynomial transformation, which usually gave an RMS error no greater than $3 \mathrm{~m}$ (3rd polynomial, approx. 20 points per sheet).

The last step in the georeferencing was the transformation of all rectified materials into the PUWG92 (EPSG: 2180) common coordinate system. Ultimately, 450 raster images were georeferenced with the help of more than 10,000 control points.

Source materials in the vector format (the LPIS cadastral layer from 2008) did not require georeferencing. However, at the district boundaries data did not meet basic topological conditions (overlapping parcels, gaps) as vectorization was not agreed at the supradistrict level. These errors were later removed during preparation of a coherent database for further analysis.

\section{Land ownership classification}

Land, according to the most general ownership classification, can be divided into state properties and private properties (including commons). In the Austrian censuses of the 19th century, land was divided into major 
estate owned by the manors, and minor estate held by peasants, which was a consequence of the state's feudal organization of territory. In the descriptive part of the land cadastre from 1852, including the alphabetical lists of owners, this division is not explicitly formulated. Instead, each individual owner is given a title with regard to their legal and social status, for example: peasant (Bauer); a villager with no or little land (Häusler); gardener (Gärtler), and landlord (Grundherr). In addition, in the alphabetical list of owners, parishes (Pfarre) were listed; the church (Kirche); the Jewish Religious Community (Judengemeinde); village community (Gemeinde), and the Austrian State itself (Cammeral Herrschaft).

Finally, for the purposes of this work, five types of landowners were distinguished for the feudal period: the Austrian State (the acquirer of royal estates after the partition of Poland); the clergy (including churches of different denomination as well as the Jewish Religious Community); the gentry (landlords and other representatives of the nobility); peasantry, and the community (Tab. 2).

Until World War II, land ownership corresponded to the hierarchical division of society (estates, classes). In the communist era, the old social order was abolished and private property was significantly reduced. Most land subsequently became state land, so it was reasonable to account in the land ownership classifications not only for landowners, but also institutional holders of state-owned land. The Decree of 1955 (Journal of Laws 1955 No. 6, item 32) established 14 official classes of landowners/landholders, the socalled register groups. These groups were the starting point for the development of the classification of landowner types in the 1960s that are used in this work. Eight main types of landowners/landholders were distinguished, including four classes of state-land holders: the 'State Forests' National Forest Holding (Państwowe Gospodarstwo Leśne PGL); the 'State Farms' National Agricultural Holding (Państwowe Gospodarstwo Rolne - PGR); The State Land Fund (Państwowy Fundusz Ziemi - PFZ), and 'other state units'. Private owners were divided into individuals, cooperatives represented by the Agricultural Cooperative (Spółdzielcze Gospodarstwo Rolne - SGR), the church and community represented by the National Communal Council (Gromadzka Rada Narodowa - GRN) (Tab. 2).

After the economic transformation of the 1990s, a considerable part of the land was re-privatized. A new main division of landowners into natural persons (individuals) and legal persons (including the State Treasury as representative of the State) was established. The currently applicable division into 15 register groups was introduced by the Regulation of the Minister of Regional Development and Construction on the registration of land and buildings, dated 29 March 2001 (Journal of Laws 2001 No. 89, item. 454).

Table 2. Classification of landowners in the 3 socio-political systems

\begin{tabular}{|c|c|c|c|}
\hline & $\begin{array}{l}\text { Landowners under feudalism, } \\
1852\end{array}$ & $\begin{array}{l}\text { Landowners under communism, } \\
1965\end{array}$ & $\begin{array}{l}\text { Landowners under capitalism, } \\
\qquad 2008\end{array}$ \\
\hline \multirow[t]{4}{*}{ State land } & Austrian State & State Farms & Agricultural Property Agency \\
\hline & & State Forests & State Forests \\
\hline & & State Land Fund & other state unit \\
\hline & & other state unit & \\
\hline \multirow[t]{4}{*}{ Private land } & clergy & church & church \\
\hline & community & community & community \\
\hline & gentry & Agricultural Cooperative & company \\
\hline & peasantry & individuals & individuals \\
\hline
\end{tabular}


In this article, 7 main types of landowners/landholders were distinguished for the capitalist era, including three classes of stateland holders: the 'State Forests' National Forest Holding, the Agricultural Property Agen$\mathrm{cy}^{3}$ and 'other state units'. Private owners were divided into individuals, companies, the church and community, represented by local government (Tab. 2).

\section{Correspondence analysis}

To determine similarities between landowners, a multiple correspondence analysis (MCA) was carried out, with the results displayed in a 2D geometric visualisation (for details see Greenacre 1984; Benzécri 1992). Essentially, the interpretation of the two-dimensional MCA scatterplot is intuitive - objects located close to each other are similar, objects located far apart are different. However, interpreting distance between classes of different variables as a measure of similarity is not permitted, and should instead be understood as a measure of coexistence. Landowners from different sociopolitical systems located close together have a large proportion of 'common' land, located far away 'share' small proportions of their land.

\section{Results}

In 1852, the gentry and peasantry were the two dominant groups of landowners in the Upper Wiar River Basin (Fig. 3). Each of these groups owned $42.5 \%$ of the total basin area. Noblemen appeared in the landholder records as owners of whole villages, but actually only manor areas were in their possession and under their management - so-called dominia. The remaining land in the villages

3 The Agricultural Property Agency (Agencja Nieruchomości Rolnych - ANR) - a state institution established in 2003 in place of the Agricultural Property Agency of the State Treasury, which had the task of acquiring, restructuring and privatizing the agricultural property of the former 'State Farms' and the State Land Fund. belonged to other groups of owners, mainly peasants. Another significant owner was the Austrian State, having nearly 2,000 ha, equivalent to $8.5 \%$ of the river basin. These lands formed a compact whole in the village of Makowa and Sopotnik, including the Turnica Forest, which in the 19th century belonged to the Dobromil Forest District. Before the partition of Poland, the Turnica Forest, together with the neighbouring villages of Makowa and Sopotnik, belonged to the royal estates. The clergy (representatives of Christian churches as well as the Jewish Religious Community) owned 2\% of the basin, accounting for just over 450 ha. The distinctive strips of land belonging to the clergy are parochial parcels delimited long ago, at the time of village establishment. Those parcels extend across the main axis of the settlement, mostly through the centre of the village. Usually, temples were built on those parcels. Longitudinal parochial parcels are especially visible in the villages founded in the 15th and 16th century under Wallachian law. In older villages of Ruthenian origin (Rybotycze, Trójca, Huwniki), and in High Medieval settlements adjacent to strongholds (Pacław, Kopyśno), parochial lands do not form compact strips of land. Instead, they resemble round clusters, corresponding to the shape of the ancient Ruthenian farmsteads, with accompanying scraps of land loosely scattered across neighbouring hills.

The last landowner from 1852 taken into account was the community, namely all the inhabitants of a village. The commons primarily comprised rural roads and small pastures close to settlements, often along streams and rivers, used for poultry grazing, moving livestock or trade. The village community often owned a separate pasture for a breeding bull (e.g. in Makowa), and a number of scattered minor forests that were generally over-exploited. Commons particularly occur in settlements of the oldest origin, and in royal villages. In total, they covered 1,076 ha of the Wiar River Basin (4.6\%). 
The second reconstructed state of land ownership is from the mid-1960s (Fig. 3). At that time, most of the land $(12,732$ ha, $54.6 \%)$ was held by the 'State Forests' National Forest Holding. These lands were part of 4 forest districts: Wojtkowa, Nowe Sady, Bircza and Krasiczyn. The 'State Farms' held 3,686 ha of land in 16 villages. At the end of the 1950s, part of the land previously belonging to 'State Farms' was handed over to an Agricultural Cooperative formed by communist immigrants from Greece (Maryański 1963). By the 1960s, the cooperative held more than 1,600 ha of agricultural land in the villages of Trzcianiec, Roztoka and Graziowa.

More than $7 \%$ of the basin was under the management of the State Land Fund, which held land properties confiscated and nationalized by the Decree on land reform of 1944 and the Decree of 1949 on the acquisition by the State of land properties no longer under owners' management (Jarosiewicz 2007), and which were neither incorporated into 'State Forests', nor 'State Farms'.

Land owned by individuals accounted for slightly more than $11 \%$ of the study area. Another 3.3\% were in the possession of the community (National Communal Council). Local roads, minor forests and fields, rural dayrooms, some fire stations, schools and watercourses all belonged to the community.

The remaining state-owned land was assigned as 'other state unit'. Included in this class were land properties held by several state bodies across the country, such as District and Provincial National Councils, Militia, State Fire Service, the Directorate of Posts and Telegraphs in Krakow, the Regional Management Board of Waterways in Sandomierz, Regional Dairy Cooperative in Przemyśl, and others. Altogether, these lands constituted $1.3 \%(300 \mathrm{ha})$ of the study area. The smallest class $(0.2 \%)$ was church land, much truncated by post-war confiscation and nationalization. In the 1960s, unlike in the pre-war period, only the Roman Catholic Church possessed land property (45 ha), including the Franciscan Monastery in Kalwaria Pacławska and churches in Rybotycze and Nowosielce Kozickie.

The third and last reconstructed state of land ownership is from 2008 (Fig. 3). At that time, most of the land $(15,751 \mathrm{ha}$, 67.5\%) was held by 'State Forests' in two forest districts, Bircza and Krasiczyn. The second major holder of state-owned land (970 ha) was the Agricultural Property Agency. Individuals owned more than 4,550 ha, which accounted for $19.5 \%$ of the study area, while community, represented by local government, owned 1,000 ha. Church property accounted for $1.9 \%$ of the Upper Wiar River Basin. As part of the compensation for lost estates in the post-war period, large areas of agricultural land in the villages of Sopotnik and Leszczyny were passed in the 1990s to the Greek Catholic Church. In Łomna village, over 56 ha had belonged since 1999 to the Caritas Ordinariate of the Polish Army. Less than $1.1 \%$ of the basin in 2008 lay in the hands of private companies, with more than 117 ha belonging to the owner of the hotel 'Arłamów' (the former hunting lodge of the Council of Ministers Office). Every other state body managing the land of the State Treasury was classified as 'other state unit', with 340 ha total.

\section{Changes in land ownership}

Taking into account the three states of land ownership in the 156-year period of the study does not allow for determination of the full dynamics of ownership structure, but it does give some idea of its transformations. The three states of land ownership examined are born of three different socio-political systems, which are perfectly reflected in their land ownership structure: feudalism (the period of industrial revolution), communism (real socialism) and capitalism. The present paper discusses changes in land ownership between consecutive pairs of states (1852 $\rightarrow$ $1965,1965 \rightarrow 2008)$, as well as the trajectories of the changes between 3 points in time (1852 $\rightarrow$ 1965 $\rightarrow$ 2008). 


\section{Land ownership changes from feudalism to communism}

In the period between 1852 and 1965 a total of 38 of 40 possible different transitions of land ownership were recorded (5 classes in $1852 \times 8$ classes in 1965). The acquisition of land by 'State Forests' owned in 1852 by the gentry was the transition involving the largest area (nearly 7,000 ha), of more than $70 \%$ of all land owned by the gentry in 1852 and less than 55\% of the "State Forests" land in 1965. Detailed analysis showed that this change almost exclusively affected manor forests, from old growth Carpathian beech forest to sparse riparian shrubs.

The second largest area transition $(3,258 \mathrm{ha})$ was the acquisition of peasantry land by 'State Forests'. Mostly, this included higher-altitude, overgrown pastures and fields in abandoned villages, mainly in Borysławka, Sopotnik, Jamna Górna, Jamna Dolna and Grqziowa.

As much as $72 \%$ of the land $(2,600 \mathrm{ha})$ held in 1965 by 'State Farms' had been in the hands of the peasantry in 1852. Only 800 ha of land belonging to the gentry came under the management of 'State Farms'. The land held by the Austrian State (96\%) was taken over by 'State Forests'. Most of the peasantry's land acquired by the State Land Fund (PFZ) lay in the village of Makowa (in the former lands of German colonists). In villages with a continuity of settlement, most of the peasantry land had remained in the hands of individual owners. By contrast, only 750 ha of land owned by the gentry (of nearly $10,000 \mathrm{ha}$ ) remained in private hands. Out of 460 ha belonging to the clergy, only 6 ha was still owned by the church in 1965 .

\section{Land ownership changes from communism to capitalism}

From 1965 to 2008, a total of 51 of 56 possible different transitions of land ownership were recorded ( 8 classes of $1965 \times 7$ classes in 2008). By far, most of the land (almost $12,700 \mathrm{ha}$ ) remained in the hands of 'State Forests'. They also expanded their possession in the Upper Wiar River Basin by more than 3,000 ha (24\%), taking over $57 \%$ of the land belonging in 1965 to 'State Farms' and 38\% of the land belonging to the Agricultural Cooperative. That land was mainly agricultural land (now partly forested and partly used as meadows) in the villages of Jamna Dolna, Jamna Górna, Trójca and Grąziowa, acquired from the liquidated Military Agricultural Holding (Wojskowe Gospodarstwo Rolne - WGR), after the economic transformation of the 1990s.

In 2008 the Agricultural Property Agency held 775 ha of land in the village of Trzcianiec, which had belonged in 1965 to the Agricultural Cooperative and which accounted for almost $80 \%$ of the Agricultural Property Agency's land and 49\% of Cooperative land. Over $90 \%$ of the land belonging to individuals still remained their property. As a result of land privatization, 2,100 ha came into the hands of individuals, of which more than 900 ha came from both the State Land Fund and 'State Farms'. The privatized former 'State Farms' land lies in the northern part of the basin, in the villages of Łodzinka Górna, Łodzinka Dolna, Rybotycze, Kopyśno, Posada Rybotycka and Huwniki.

In 2008, the church owned 300 ha of land that had belonged in 1965 to 'State Farms', representing 68\% of all church land at the time. That land, located in the villages of Sopotnik and Leszczyny near the contemporary border with Ukraine, now belongs to the Greek Catholic Church. Land belonging in 1965 to the State Land Fund in 2008 was, besides individual owners, in the hands of 'State Forests' (290 ha), and the community ( $230 \mathrm{ha})$. These lands accounted for $18 \%$ and $14 \%$ of the State Land Fund, respectively.

\section{Land ownership trajectories}

$1852 \rightarrow 1965 \rightarrow 2008$

As a result of the joint intersection of 3 vector layers showing the states of land ownership representative of feudalism, communism and capitalism, 213 of 280 possible trajectories of change were recorded ( 5 classes in $1852 \times 8$ classes in $1965 \times 7$ classes in 2008 ) 
(Fig. 2). The three main trajectories, covering in total almost $52 \%$ of the river basin, relate to the transition of land formerly owned by the gentry, peasantry and the Austrian State into the hands of 'State Forests' before 1965, where it remained under their management until at least 2008. Lands falling in the trajectory 'gentry $\rightarrow$ State Forests $\rightarrow$ State Forests' $(6,950 \mathrm{ha})$ are found mainly in the upper parts of the Chwaniów and the Braniów Ridge, and in the north-western part of the basin. Land included in the trajectory 'peasantry $\rightarrow$ State Forests $\rightarrow$ State Forests' $(3,230 \mathrm{ha})$ is located on slopes, mainly in the centre of the study area (the villages of Jamna Dolna and Borysławka). Land belonging to the trajectory 'Austrian State $\rightarrow$ State Forests $\rightarrow$ State Forests' $(1,890$ ha) is concentrated in the Suchy Obycz Massif on the upper course of the Turnica stream.

Into the trajectory 'peasantry $\rightarrow$ State Farms $\rightarrow$ State Forests' falls 1,620 ha of land concentrated along an old axis of settlements in abandoned villages, mainly in Jamna Dolna, Jamna Górna, Łomna, Krajna, Trójca and Posada Rybotycka. The trajectory 'peasantry $\rightarrow$ Agricultural Cooperative $\rightarrow$ State Forests' (390 ha) is represented by lands on gentle slopes located mostly in the village of Graziowa along the Wiar River and the Mszaniec stream, as well as in the village of Roztoka (called Rostoki in 1852). The distinctive strip of land in the village of Trzcianiec represents the trajectory 'gentry $\rightarrow$ Agricultural Cooperative $\rightarrow$ Agricultural Property Agency' (260 ha). Also relatively easy to extract are: lands belonging to the trajectory 'peasantry $\rightarrow$ Agricultural Cooperative $\rightarrow$ Agricultural Property Agency' (also in the village of Trzcianiec); 'community $\rightarrow$ State Forests $\rightarrow$ State Forests' (the so-called German Forest in the village Makowa); 'gentry $\rightarrow$ State Farms $\rightarrow$ individuals' (patches of land in the north of the basin), and 'peasantry $\rightarrow$ State Farms $\rightarrow$ church' (in the village of Leszczyny and Sopotnik). Lands of other trajectories form a mosaic of small patches belonging in 1852 primarily to the peasantry, the community and the clergy.

A two-dimensional scatterplot of multiple correspondence analysis (MCA) involving 3 variables, shows 3 clusters of landowners (actually clusters of their land) (Fig. 4). The first group is composed of land belonging

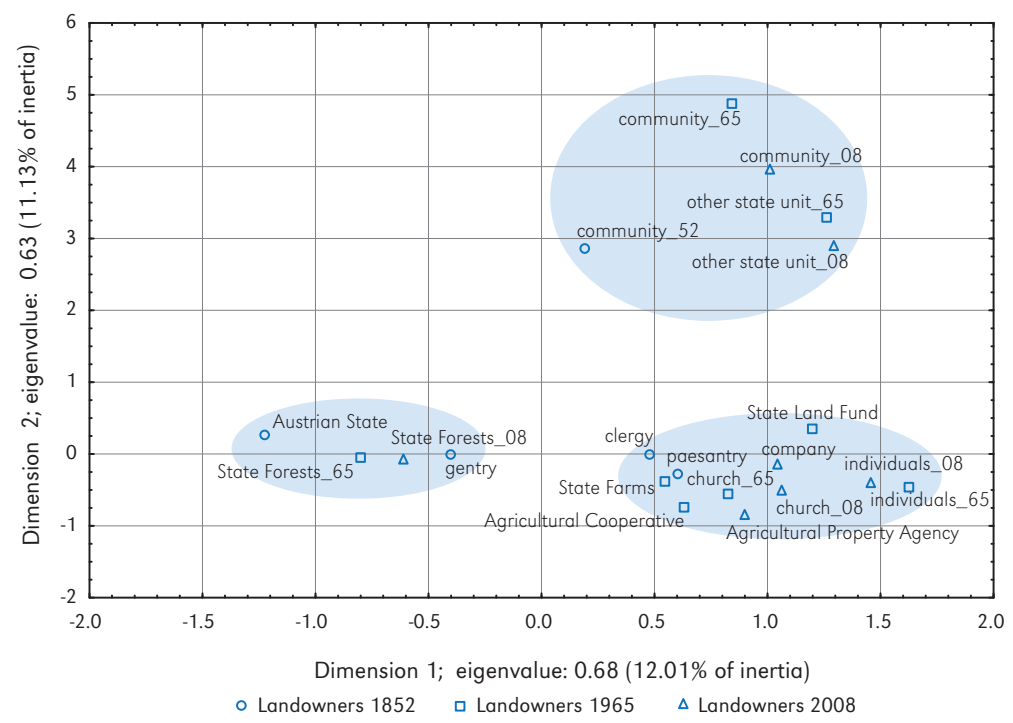

Figure 4. Two-dimensional scatterplot of the multiple correspondence analysis (MCA). Variables included: landowners 1852, landowners 1965, landowners 2008. Input table - the Burt table $20 \times 20$ 
to 'State Forests' in 1965 and 2008, and land of the Austrian State and the gentry in 1852. It seems reasonable to suspect that what links these classes (amongst other things), is that part of the land permanently covered with forest.

The second dense cluster of 11 landowner classes is located in the lower right corner of the chart. The common, distinguishing features of these landowners are their permanent settlement areas and permanent farmlands. The last, loose group, is composed of land owned in all three time slices by local and regional authorities representing both the community and the State (the 'other state units'). The commonality in this case is not the continuity of land cover, nor any selected class of land cover, but seems - besides the simple succession of those classes - to be just the diversity of land cover.

\section{Concluding discussion}

In this paper, spatially explicit changes were analysed between three states of land ownership under three different socio-political systems, or (after Cosgrove 1984) socio-economic formations. Similar studies haven't been found in world literature so far.

The analysis of similarities and overlapping of different landowner classes using a scatterplot of multiple correspondence analysis shows specific relationships between consecutive ownership divisions. The results obtained are highly reliable, as input materials reflect the true ownership structure with a resolution to a single parcel (boundaries defined with an accuracy of $1 \mathrm{~m}$ ). The large datasets used $(63,451$ parcels in three time slices in an area of over 23,300 ha) also favourably affect the reliability and representativeness of the results.

Even preliminary analysis of the results shows close links between land cover and ownership structure. Almost all the land of the Austrian State (formerly royal) was taken by 'State Forests' after the war, and have remained with them to this day. That land, except for a few temporal mid-forest clearings, is covered by permanent forest (in the time horizon of the research). A similar situation applies to the land covered by permanent forest and once owned by the gentry. The majority of it came en bloc under the management of 'State Forests' after the war, and it is the presence of permanent forest that distinguishes and joins the land owned by the Austrian State, the gentry and 'State Forests'.

The MCA chart indicates a significant overlap of land owned by the community in every socio-political system, and their close similarity (in the size of single transitions) with land held after the war by 'other state units'.

Commons constituted about $4 \%$ of the river basin in each socio-economic formation. Spatial analysis of 'inheritance' trajectories shows, however, that only approx. $20 \%$ of the land belonging to the community in each time slice is land that, throughout the entire time horizon, belonged continuously to that landowner.

Ultimately, this proves a fairly low durability of ownership relations and a fragile attachment to land in the case of commons. It also indicates just how dynamic the ownership structure is as a whole. Relatively speaking, the most deterministic is the fate of state-owned land. Over 95\% of stateowned land in 1852 remained at least for the next 160 years in the hands of the state. Also, it is the state that was the biggest beneficiary of the post-war ownership overturn. The area of state-owned land increased from 8.5\% in 1852 to $78.4 \%$ in 2008 (more than nine times).

Despite extensive restitution actions begun after the political transformation of 1989 and the earlier distribution of parcels from the State Land Fund, the State reduced its holdings between 1965 and 2008 by only $5.2 \%(1210 \mathrm{ha})$. As part of the compensation for lost estates after the war, more than 400 ha had been handed over to religious associations (mainly the Greek Catholic Church). In this way, the 19th-century state of the clergy's ownership was restored almost exactly, even including the proportions of land cover classes (Fig. 5). 


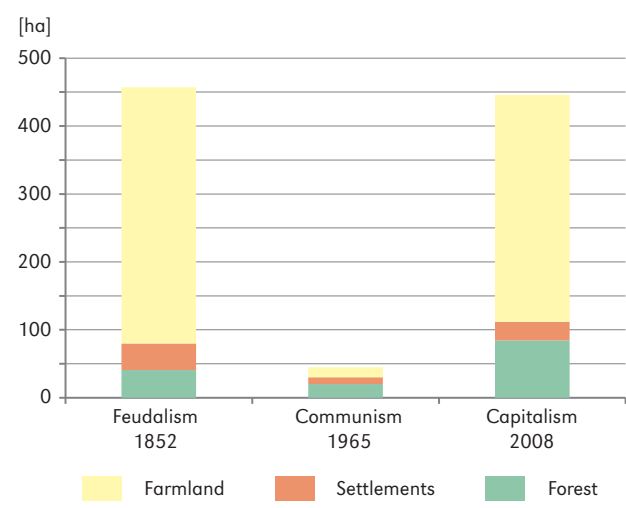

Figure 5. Land owned by the clergy in the three socio-political systems in the Upper Wiar River Basin

\section{References}

Affek A., 2013. Georeferencing of historical maps using GIS, as exemplified by the Austrian military surveys of Galicia. Geographia Polonica, vol. 86, no. 4, pp. 375-392.

Afrek A., 2015. Skutki krajobrazowe przerwania ciagłości osadnictwa [in:] J. Plit, E. Regulska (eds.), Zmiany krajobrazów kulturowych w obrazie kartograficznym, Prace Komisji Krajobrazu Kulturowego PTG, no. 28, pp. 47-65.

BenzéCRI J., 1992. Correspondence Analysis Handbook. New York: Marcel Dekker Inc.

Cosgrove D.E., 1984. Social Formation and Symbolic Landscape. Madison: University of Wisconsin Press.

GreenaCre M.J., 1984. Theory and applications of correspondence analysis. New York: Academic Press.

Jarosiewicz M., 2007. Państwowa własność nieruchomości rolnych [in:] M. Jarosiewicz, K. Kozikowska (eds.), Prawo rolne, Kraków, Warszawa: Wolters Kluwer Polska.

Surowiec S. (ed.), 1982. Ewidencja gruntów. Warszawa: PWN.

\section{Acknowledgements}

This work was supported by the Polish National Science Centre [Grant No. NN 305 058 940].

Editors' note:

Unless otherwise stated, the sources of tables and figures are the author's, on the basis of their own research.
The Decree dated 6 September 1944 on conducting the land reform (Journal of Laws 1944 No. 4, item 17).

The Decree dated 2 February 1955 on the registration of land and buildings (Journal of Laws 1955 No. 6, item 32).

The Decree dated 27 July 1949 on the acquisition by the State of land properties no longer under owners' management (Journal of Laws 1949 No. 46, item 339).

The Regulation of the Minister of Regional Development and Construction on the register of land and buildings dated 29 March 2001 (Journal of Laws 2001 No. 89, item 454).

MARYAŃSKI A., 1963. Współczesne migracje ludności w południowej części pogranicza polsko-radzieckiego i ich wpływ na rozmieszczenie sit wytwórczych tego obszaru. Kraków: WSP.

WOLSKI J., 2000. Austriacki kataster podatku gruntowego na ziemiach polskich oraz jego wykorzystanie w pracach urzadzeniowych $i$ badaniach naukowych. Polski Przeglad Kartograficzny, vol. 32, no. 3, pp. 199-212.

WolskI K., 1956. Osadnictwo dorzecza górnego Wiaru w XV wieku. Annales Universitas Marie Curie Skłodowska, Sectio B, no. XI.1, pp. 1-47. 


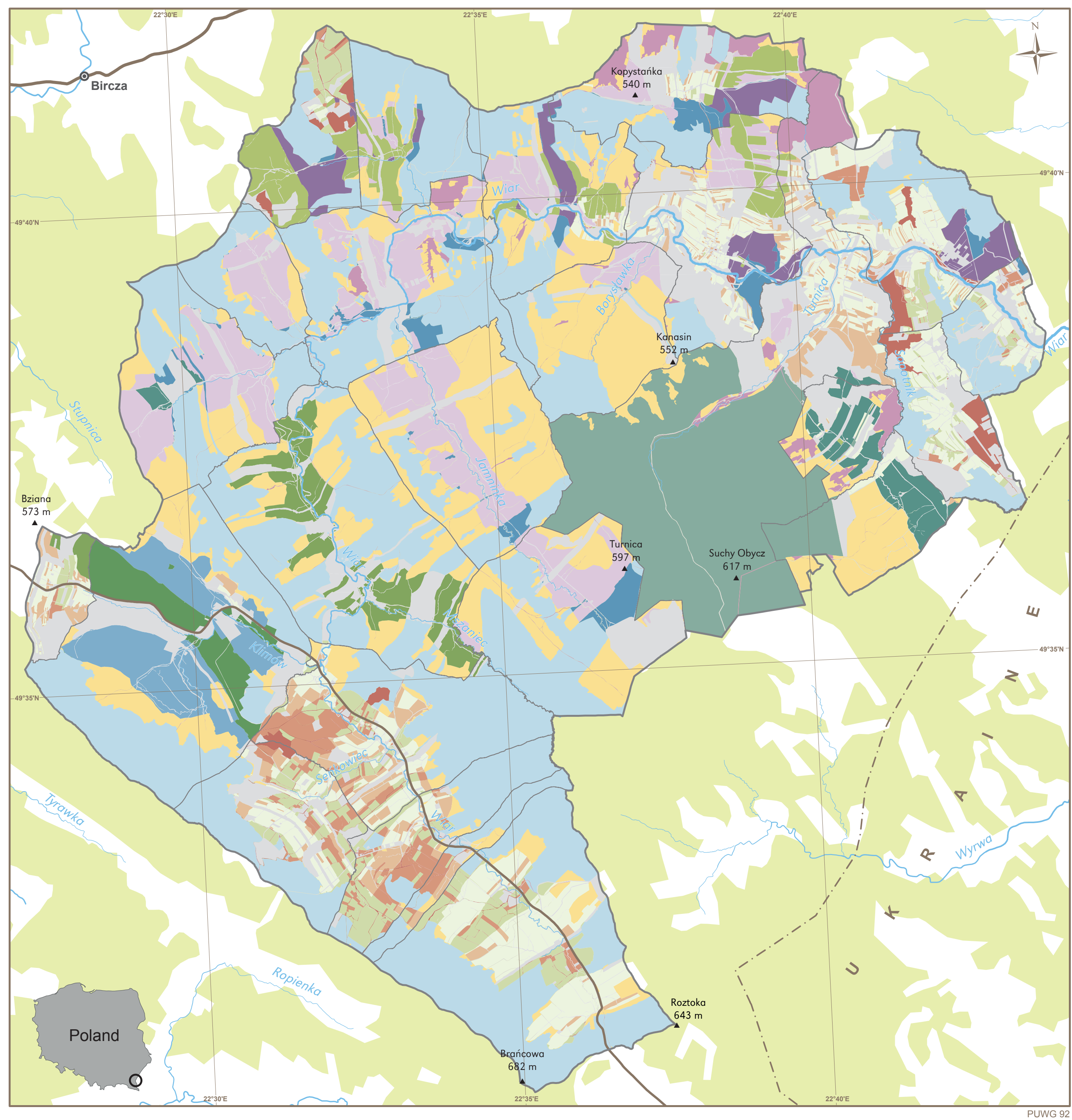

LAND OWNERSHIP CHANGES

IN THE UPPER WIAR RIVER BASIN

LAND OWNERSHIP TRAJECTORIES

FEUDALISM 1852 COMMUNISM 1965 CAPTALLSM 200

$\begin{array}{lll}\text { gentry State Forests' } & \text { State Forests }\end{array}$

peasantry State Forests State Forests

Austrian State State Forests

peasantry individuals

peasantry State Farms

gentry

individuals

peasantry

peasantry

ate Land Fun

peasantry

Agricultural coope

State Farms

State Forests

State Farms

gentry

peasanty

Agricultural Cooper

State Land Fund

State Farms

Agricultural Cooperative

Agricultural Cooperative

gentry

peasanty

community

State Forests

s

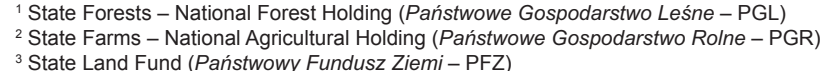

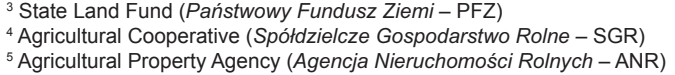

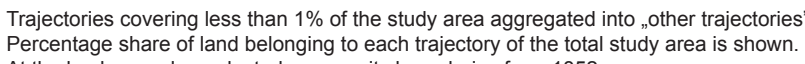

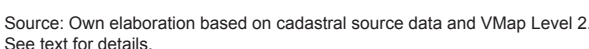

\section{Cadastral communities in 1852}

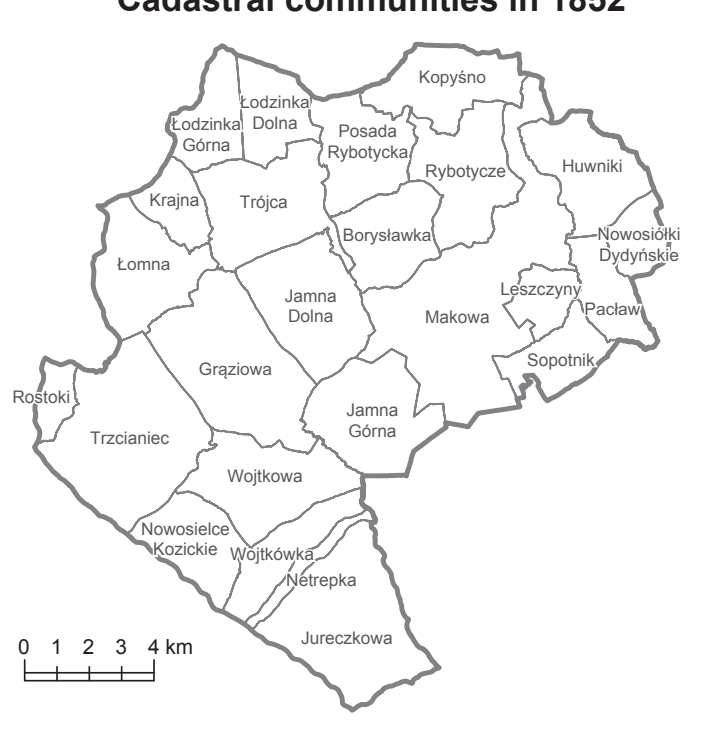

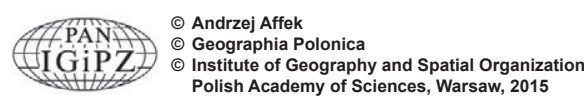

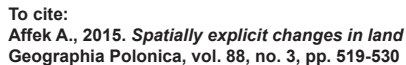




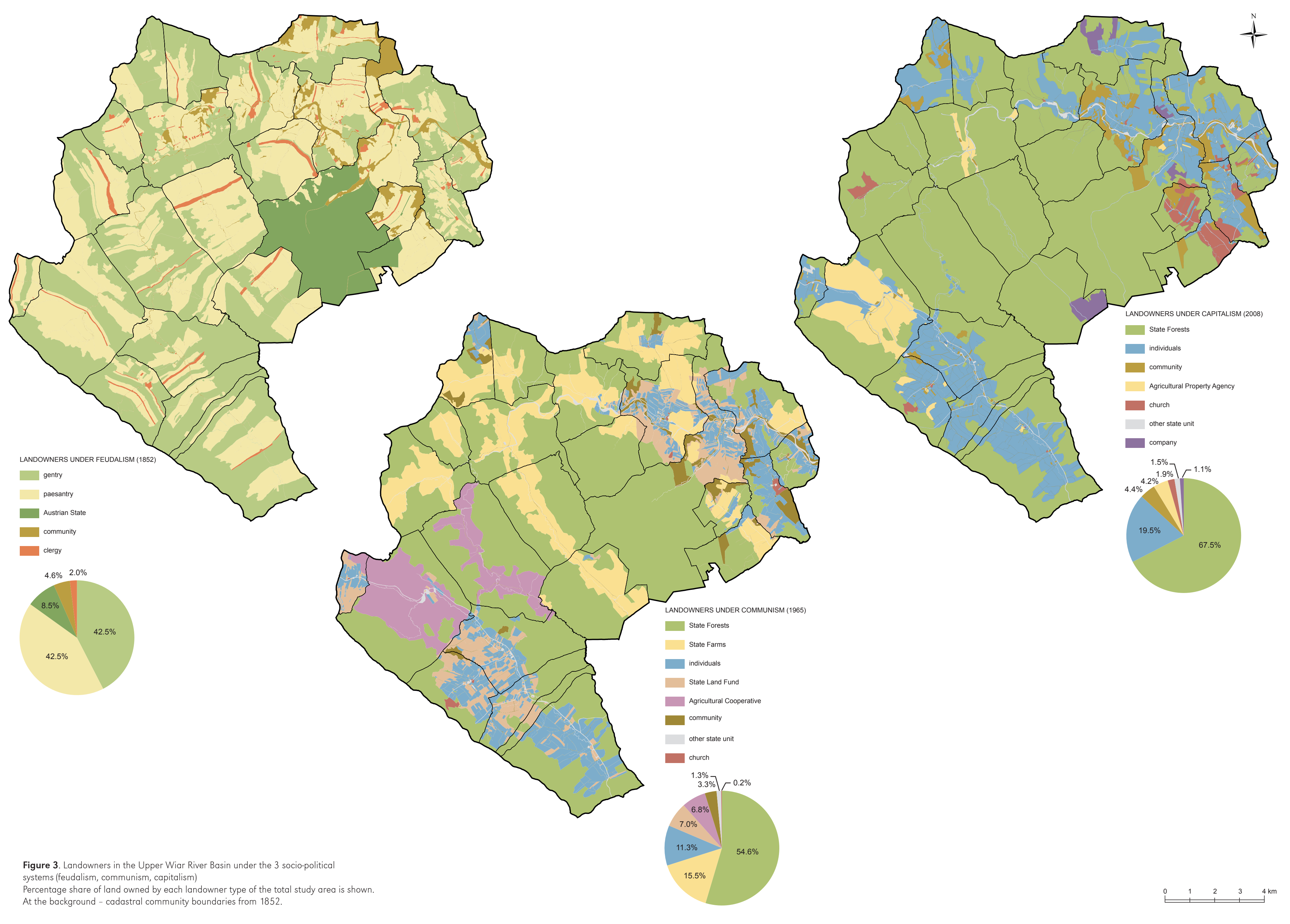


http://rcin.org.pl 